\title{
Effects of timing of corn silage supplementation on digestion, fermentation pattern, and nutrient flow during continuous culture fermentation of a short and intensive orchardgrass meal
}

\author{
P. Gregorini, ${ }^{11,2}$ K. J. Soder, ${ }^{*}$ and G. Waghornt \\ *USDA-ARS Pasture Systems and Watershed Management Research Unit, Bldg. 3702, Curtin Road, University Park, PA 16802 \\ †DairyNZ Ltd., Private Bag 3221, Hamilton, New Zealand
}

\begin{abstract}
Using a dual-flow continuous culture fermenter system, this study evaluated the effect of timing of corn silage supplementation on ruminal digestion and nutrient flows following a short and intensive orchardgrass herbage meal. Treatments included $28 \mathrm{~g}$ dry matter (DM) of corn silage added either $9 \mathrm{~h}$ (9BH; $0700 \mathrm{~h}$ ) or $1 \mathrm{~h}(1 \mathrm{BH} ; 1500 \mathrm{~h}$ ) before adding $42 \mathrm{~g} \mathrm{DM}$ orchardgrass herbage or no corn silage (control; $70 \mathrm{~g}$ DM herbage). Herbage was fed as follows: $66 \%$ of the total herbage meal at $1600 \mathrm{~h}, 22 \%$ at $1720 \mathrm{~h}$, and the remaining $12 \%$ at $1840 \mathrm{~h}$. Effluent was analyzed for organic matter $(\mathrm{OM})$, crude protein $(\mathrm{CP})$, and neutral detergent fiber (NDF). Purine concentrations in effluent and bacterial isolates were used to estimate the partition of effluent $\mathrm{N}$ flow into bacterial and nonbacterial fractions, and to calculate true OM digestibility. Fermenters were sampled for $\mathrm{pH}$, volatile fatty acids (VFA), and $\mathrm{NH}_{3}-\mathrm{N}$ at $0730,1100,1530,1600,1720,1840$, and $2000 \mathrm{~h}$ on d 10 . Data were analyzed as a $3 \times 4$ Latin square experimental design. True digestibilities for OM (average of $78.5 \%$ ) and CP (average of 84.6\%), and apparent NDF digestibility (average of $82.7 \%$ ) were not affected by treatment. Mean ruminal $\mathrm{pH}$ was lower for $9 \mathrm{BH}$ than for $1 \mathrm{BH}$, averaging 5.6 and 6.5, respectively. Molar proportions of acetate were not affected by treatment. Propionate concentration was greater for 9BH than for $1 \mathrm{BH}$, averaging 20.5 and $18.1 \mathrm{~m} M$, respectively. Diurnal patterns of $\mathrm{pH}, \mathrm{NH}_{3}-\mathrm{N}$, and acetate:propionate ratio were affected by treatment: $9 \mathrm{BH}$ had the lowest values

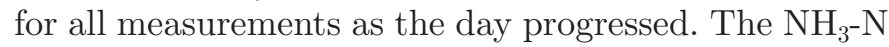
concentration and effluent $\mathrm{NH}_{3}-\mathrm{N}$ flow were higher for $1 \mathrm{BH}(11.4 \mathrm{mg} / 100 \mathrm{~mL}$ and $0.26 \mathrm{~g} / \mathrm{d}$, respectively) than for $9 \mathrm{BH}(8.8 \mathrm{mg} / 100 \mathrm{~mL}$ and $0.20 \mathrm{~g} / \mathrm{d}$, respectively). Effluent $\mathrm{NH}_{3}-\mathrm{N}$ flow (as a \% of total $\mathrm{N}$ flow) was the lowest for 9BH. Bacterial efficiency was not affected by
\end{abstract}

\footnotetext{
Received November 26, 2009.

Accepted March 15, 2010.

${ }^{1}$ Corresponding author: Pablo.Gregorini@dairynz.co.nz

${ }^{2}$ Present address: DairyNZ Ltd., Private Bag 3221, Hamilton, New Zealand.
}

treatments, with a mean of $10.5 \mathrm{~g}$ of $\mathrm{N} / \mathrm{kg}$ of OM truly digested. Under the same resource allocation (pasture plus supplement), a simple change in timing of corn silage feeding ( 9 rather than $1 \mathrm{~h}$ before an orchardgrass herbage meal) may alter ruminal fermentation pattern. These changes could increase the glucogenic nutrient supply and improve $\mathrm{N}$ utilization by reducing ammonia $\mathrm{N}$ losses.

Key words: corn silage, supplementation, herbage digestion, nutrient supply

\section{INTRODUCTION}

Pastoral grazing enables cost-effective milk production in temperate climates (Holmes et al., 2002; Bargo et al., 2003a). However, in pastoral systems farmers are faced with the challenge of continuous growth of herbage while maintaining its quality, minimizing feed costs, and providing concentrates or conserved forages when herbage quantity or quality is decreased due to seasonal changes. Nitrogen fertilizer, as urea, is widely and successfully used to stimulate herbage growth; however, excessive urea application has led to $\mathrm{N}$ leaching and contamination of ground water, as well as losses of $\mathrm{N}_{2} \mathrm{O}$ (Tamminga, 1996; de Klein and Ledgard, 2001). Strategic grazing management that reduces the time at pasture (4-8 h/d) has been proposed to reduce pugging and treading damage in wet conditions to improve pasture production and utilization (Blackwell, 1993; Gregorini et al., 2008; Kennedy et al., 2009). Limited access to pasture forces cattle to consume most of the daily herbage DMI in less than $4 \mathrm{~h}$ (Chilibroste et al., 2007; Gregorini et al., 2008, 2009). This type of management has other benefits, including less urinary $\mathrm{N}$ deposition, which can reduce nitrates leaching to ground water (McLeod et al., 2009). However, acute restriction of time available to graze has reduced ruminal OM digestion in beef heifers (Gregorini et al., 2008) and lowered herbage DMI and milk production in dairy cows (Mattiauda et al., 2003; McLeod et al., 2009; Pérez-Ramirez et al., 2009) so that supplementation is required to maintain nutrient intake and productivity. 
Whole-plant corn (Zea mays L.) silage is often used as a supplement in pastoral systems because it provides energy with low inputs of $\mathrm{N}$, diluting the excessive $\mathrm{N}$ often supplied by herbage. Few studies have focused on the importance of the timing of corn silage or concentrate supplementation. For example, Adams (1985) showed evidence of greater ADG in beef cattle supplemented in late morning when cattle normally do not graze. Mitani et al. (2005) reported greater milk N output by dairy cows when corn silage was fed immediately before rather than after a grazing period. In addition, Gekara et al. (2005) found that DMI, grazing time, and pasture utilization were greater when lactating beef cows were supplemented in the morning $(0700 \mathrm{~h})$ instead of the evening $(1800 \mathrm{~h})$. From these studies emerges the concept that timing of corn silage supplementation may alter herbage digestion and ruminal metabolism, changing the nutrient supply to the animal. These studies reported direct effects on DMI, ADG, and milk production, but there is little information concerning the ruminal effects of timing of supplementation.

Continuous culture fermentation systems have been successfully used for rapid evaluations of ruminal responses to hypothetical feeding scenarios (Kolver and de Veth, 2002; Bargo et al., 2003b; Wales et al., 2004). The objective of this study was to use a dual-flow continuous culture fermenter system to measure the effect of timing of corn silage supplementation, either 9 or 1 $\mathrm{h}$ before a short and intensive herbage meal, on rumen microbial fermentation and nutrient flows.

\section{MATERIALS AND METHODS}

\section{Site, Experimental Design, Treatments, and Diets}

The study was conducted at the USDA-ARS Pasture Systems and Watershed Management Research Unit (University Park, PA). Three treatments were randomly applied to a 4-unit dual-flow continuous culture fermenter system using a replicated Latin square design with 2 squares and 3 periods. The first square was complete and used 3 fermenters, whereas the second square was incomplete, using only the fourth fermenter. For each period, there was 1 fermenter per treatment, and the fourth fermenter was used to duplicate one of the treatments in each run (period). Each period consisted of a 7-d diet adaptation period followed by a $3-\mathrm{d}$ sampling period. Treatments included $28 \mathrm{~g} \mathrm{DM}$ of corn silage fed $9(\mathbf{9 B H})$ or $1 \mathrm{~h}(\mathbf{1 B H})$ before $42 \mathrm{~g} \mathrm{DM}$ of orchardgrass (Dactylis glomerata L.) herbage or no corn silage (control; CON, 70 g DM of herbage). Herbage was fed to simulate the ingestion rate dynamics during a grazing bout (Gregorini et al., 2008); 66\% (27.7 g) of the total herbage meal was fed at $1600 \mathrm{~h}, 22 \%$ (9.4 g) at $1720 \mathrm{~h}$, and the remaining $12 \%(4.9 \mathrm{~g})$ at $1840 \mathrm{~h}$. Corn silage was fed in 2 equal portions 30 min apart. Herbage was harvested from orchardgrass pastures at the Russell Larson Agricultural Research Center

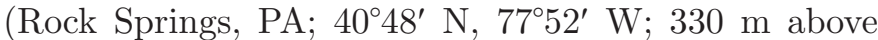
sea level). All the orchardgrass herbage for the experiment was harvested at one time during the afternoon $\left(1500 \mathrm{~h}\right.$ ), frozen at $-20^{\circ} \mathrm{C}$, freeze-dried (Ultra 35 Super ES, Virtis, Gardiner, NY), and then ground through a 2-mm mesh screen (Wiley mill, Thompson Scientific, Philadelphia, PA). Corn silage was obtained from The Pennsylvania State University Dairy Research Center (University Park, PA), immediately frozen at $-20^{\circ} \mathrm{C}$, freeze-dried, and ground through a 2-mm mesh screen as above. Samples of herbage and corn silage were chemically analyzed for NDF and ADF (Ankom A200 Filter Bag Technique, Ankom Technology, Macedon, NY), CP (method 990.03; AOAC, 2000), total digestible nutrients (Weiss et al., 1992), and NSC (starch; YSI 2700 Select Biochemistry Analyzer, YSI, Yellow Springs, OH; ethanol-soluble carbohydrates; YSI; Hall et al., 1999).

\section{Continuous Culture Operation}

This experiment used a 4-unit dual-flow continuous culture system similar to that described by Hoover et al. (1989) with the following modifications: $\mathrm{pH}$ was not controlled, neither pasture nor corn silage was pelleted, and urea was added to the mineral buffer solution (Weller and Pilgrim, 1974) at a rate of $0.4 \mathrm{~g} / \mathrm{L}$. Fermenter volumes were $1,140 \mathrm{~mL}$, fed $70 \mathrm{~g}$ of $\mathrm{DM} / \mathrm{d}$, and operation was similar to Soder et al. (2007). Fermenters were fed as described above. The rumen fluid donor, a lactating Holstein dairy cow, was cared for according to the guidelines stipulated by The Pennsylvania State University Animal Care and Use Committee (IACUC \#14829), and fed a TMR ad libitum (40\% concentrate, $60 \%$ forage). Ruminal fluid was siphoned by using a hand pump from the mid rumen and held anaerobically at $39^{\circ} \mathrm{C}$ until the time of fermenter inoculation. Within 15 min after collection, each fermenter was inoculated with 1,000 $\mathrm{mL}$ of rumen fluid sieved through 2 layers of cheesecloth. In addition, approximately $25 \mathrm{~g}$ of whole ruminal digesta from the central and dorsal regions of the rumen was added to each fermenter. Solid and liquid dilution rates were adjusted to approximate 5 and $8 \% / \mathrm{h}$, respectively. Values for solids and liquid dilution rates were chosen based on studies conducted with cattle managed similarly to the treatments of the present experiment (Gregorini et al., 2008). The solids and liquid dilution rates were regulated by adjusting the buffer input rate and the liquid removal rate (filter rate). These rates were calculated using the volume of 
the fermenter vessels and the desired solid retention time and liquid dilution rate. Fermenters were constantly purged with $\mathrm{N}_{2}$ gas to maintain positive gas flow to preserve anaerobiosis. Temperature was maintained at $39^{\circ} \mathrm{C}$.

\section{Sample Collection and Analyses}

Collection of effluent samples for VFA, $\mathrm{NH}_{3^{-}} \mathrm{N}$, $\mathrm{pH}$, and bacterial harvest was similar to the methods of Soder et al. (2007). On d 7 to 10, 4-L plastic effluent jugs containing $20 \mathrm{~mL}$ of $50 \%$ sulfuric acid and submerged approximately one-third of the depth in a water bath at $4^{\circ} \mathrm{C}$ were used to collect the effluent. The solid and liquid effluent weights were recorded daily at $1100 \mathrm{~h}$. On d 8 to 10 of each period, the liquid and solid effluents were composited for each fermenter (approximately 2,000 $\mathrm{mL}$ per fermenter per period) and homogenized using a 3-L Waring Blender (Waring, New Hartford, CT). Then, a 600-mL subsample was collected and stored at $4^{\circ} \mathrm{C}$ for further DM determination by centrifuging the subsample of effluent at $15,000 \times g$ for $45 \mathrm{~min}$ and oven-drying it for 24 $\mathrm{h}$ at $102^{\circ} \mathrm{C}$ (Hoover et al., 1989). An additional 50$\mathrm{mL}$ effluent sample was squeezed through 8 layers of cheesecloth, and a $15-\mathrm{mL}$ aliquot of fluid was preserved with $3 \mathrm{~mL}$ of $25 \%$ metaphosphoric acid and $3 \mathrm{~mL}$ of $0.6 \%$ 2-ethylbutyric acid (internal standard), swirled, and then frozen at $-20^{\circ} \mathrm{C}$ for later $\mathrm{NH}_{3}-\mathrm{N}$ (Bargo et al., 2003b) and VFA analyses (Yang and Varga, 1989). The remaining effluent was freeze-dried and ground through a 1-mm screen sieve (USA Standard Testing Sieve, VWR, West Chester, PA) for OM (methods 930.15 and 942.05; AOAC, 2000), CP (micro-Kjeldahl digestion; method 976.06; AOAC, 2000; using 75-mL calibrated tubes with $\mathrm{CuSO}_{4} / \mathrm{K}_{2} \mathrm{SO}_{4}$ catalyst), and NDF (Van Soest et al., 1991) analyses . The methods of Van Soest et al. (1991) for NDF analysis were used with amylase and sodium sulfite (inclusive of ash) using the Ankom A200 Filter Bag Technique (Ankom Technology).

On the last day of each sampling period, $\mathrm{pH}$ was recorded at $0730,1100,1530,1600,1720,1840$, and $2000 \mathrm{~h}$ directly from the fermenters (model 360, Beckman Instruments, Fullerton, CA). At the same times, 15-mL aliquots were collected by pipette (Pipetman model P-10ML, Rainin Instruments, Woburn, MA), passed through 8 layers of cheesecloth, and preserved with $3 \mathrm{~mL}$ each of $0.6 \%$ 2-ethylbutyric acid (internal standard) and 25\% m-phosphoric acid (preservative) for later VFA and NH3-N analyses. Both solid- and liquid-attached microbes were harvested (Griswold et al., 1996; de Veth and Kolver, 2001) by mixing fermenter contents in a blender and straining through $53-\mu \mathrm{m}$ Nitex cloth (Wildco, Buffalo, NY). Strained contents were centrifuged at $1,000 \times g$ for $10 \mathrm{~min}$ to remove feed particles. Microbes were isolated by centrifuging the supernatant at 20,000 $\times g$ for 30 min (Beckman J2-21, Beckman Instruments, Palo Alto, CA) twice, first using saline and then using 50\% methanol (Griswold et al., 1996), and prepared for analysis by freeze-drying. $\mathrm{Pu}-$ rine concentrations (Zinn and Owens, 1986, as modified by Makkar and Becker, 1999) in effluent and bacterial isolates were used to partition effluent $\mathrm{N}$ flow into bacterial and nonbacterial fractions and to calculate true OM digestibility and flows (Stern and Hoover, 1990).

\section{Statistical Analyses}

True OM and CP digestibilities, NDF and ADF digestibilities, and nutrient flows were analyzed using a mixed model. The model included the fixed effects of treatment and period and the random effect of fermenter. Least squares means were compared by least square minimum difference, when protected by a significant $(P<0.10)$ treatment effect. The diurnal pattern of rumen microbial fermentation was analyzed in a repeated measures analysis using cubic smoothing spline models within the linear mixed model framework as described in Verbyla et al. (1999). These models were fitted using REML. For all variables except acetate:propionate ratio, there was a significant $(P<0.05)$ interaction of treatment with time of sampling; then the times were analyzed separately to further investigate the treatment effects. The data at each time point were analyzed using linear models. A value of $P<0.05$ was considered significant. GenStat 11.1 was used for all statistical analysis (Payne et al., 2008).

\section{RESULTS}

\section{Diet Composition and Nutrient Digestibility}

Dietary inputs and chemical composition of orchardgrass herbage and corn silage and the total diet are presented in Table 1. True OM and CP digestibilities were not affected by treatment (Table 2). Apparent NDF digestibility was similar for $1 \mathrm{BH}$ and $9 \mathrm{BH}$, but tended to be higher $(P<0.10)$ for CON $(84.9 \%)$ than for $9 \mathrm{BH}$ (mean $80.5 \%)$.

\section{Mean Fermenter $\mathrm{pH}$ and VFA}

Mean ruminal $\mathrm{pH}$ was highest for $\mathrm{CON}$ and lowest for 9BH $(P<0.05$; Table 2$)$. Total VFA concentration was lower $(P<0.05)$ for $\mathrm{CON}$ than for supplemented treatments, and there was no difference between $1 \mathrm{BH}$ and $9 \mathrm{BH}$. Acetate, valerate, isobutyrate, and isovalerate concentrations did not differ between treatments. 
Table 1. Chemical composition (\% of DM) of ingredients and total diet (corn silage plus herbage) composition supplied to the continuous culture fermenters

\begin{tabular}{lrcc}
\hline Parameter & $\begin{array}{c}\text { Corn } \\
\text { silage }\end{array}$ & Herbage & $\begin{array}{c}\text { Corn silage } \\
\text { plus herbage }\end{array}$ \\
\hline OM & 96.1 & 93.2 & 94.4 \\
CP & 9.8 & 23.5 & 17.7 \\
ADF & 24.2 & 32.5 & 29.2 \\
NDF & 43.6 & 55.5 & 50.3 \\
Lignin & 3.9 & 4.5 & 4.3 \\
NSC & 43.8 & 17.1 & 27.3 \\
Lipids & 2.8 & 3.9 & 3.4 \\
\hline
\end{tabular}

Molar proportions of propionate were highest $(P<$ $0.05)$ for $9 \mathrm{BH}$, whereas butyrate concentrations tended to be the highest $(P<0.10)$ for $1 \mathrm{BH}$.

\section{Diurnal Patterns of Ruminal pH, Ammonia, and VFA}

Ruminal $\mathrm{pH}$ was lowest $(P<0.05)$ for $9 \mathrm{BH}$ at the 1100 and $1600 \mathrm{~h}$ sampling times (Figure 1a). The CON diet had the highest $(P<0.05) \mathrm{pH}$ at the 1600,1720 , and $1840 \mathrm{~h}$ sampling times. For both $1 \mathrm{BH}$ and CON, $\mathrm{pH}$ decreased when either corn silage or orchardgrass herbage was fed. Despite similar circadian patterns, there were distinct differences $(P<0.05)$ in $\mathrm{NH}_{3}-\mathrm{N}$ between the 3 treatments, with lower concentrations for $9 \mathrm{BH}$ than for $1 \mathrm{BH}$ for most of the 24 -h period (Figure $1 b)$.

The patterns of total VFA concentrations, acetate:propionate ratio, and individual concentrations of acetate and propionate are shown in Figure $1 \mathrm{c}, \mathrm{d}$, $\mathrm{e}$, and $\mathrm{f}$, respectively. Both supplemented treatments differed $(P<0.05)$ from $\mathrm{CON}$ in propionate concentra- tions (Figure 1f); 9BH showed the highest values for all the measurement times except for $0730 \mathrm{~h}$, when it did not differ from CON. The propionate concentrations for the $\mathrm{CON}$ and $1 \mathrm{BH}$ treatments differed only at the first 3 sampling times (Figure 1f). The acetate:propionate ratio was lower $(P<0.05)$ for $9 \mathrm{BH}$ than for $1 \mathrm{BH}$ (Figure 1d). The $9 \mathrm{BH}$ treatment had the greatest $(P<$ $0.05)$ butyrate concentration from 1100 to $1530 \mathrm{~h}$, but treatments caused little difference in butyrate concentrations during the herbage meal (data not shown).

\section{Nitrogen Metabolism}

Results from $\mathrm{N}$ metabolism are presented in Table 3. The $\mathrm{NH}_{3}-\mathrm{N}$ concentration and the effluent flow of $\mathrm{NH}_{3}-\mathrm{N}$ from the fermenters were lowest for $9 \mathrm{BH}$, intermediate for $1 \mathrm{BH}$, and highest for $\mathrm{CON}(P<0.05)$. Total $\mathrm{N}$ flows were similar for $9 \mathrm{BH}$ and $1 \mathrm{BH}$, but the distribution of $\mathrm{NH}_{3}-\mathrm{N}$ and non- $\mathrm{NH}_{3}-\mathrm{N}$ in effluents differed $(P<0.05)$ between treatments. Bacterial $\mathrm{N}$ and efficiency of bacterial protein synthesis per kilogram of OM truly digested were not affected by treatment.

\section{DISCUSSION}

\section{OM and NDF Digestibility}

The true OM digestibility in the present study was slightly lower than other comparable continuous culture fermentation studies in which orchardgrass was the main component of the diet. For example, Bargo et al. (2003b) reported true OM digestibilities values around 83\%; however, the level of NDF of their orchardgrass

Table 2. Nutrient digestibility and ruminal fermentation of orchardgrass herbage only (CON) and orchardgrass herbage plus corn silage fed $1(1 \mathrm{BH})$ or $9(9 \mathrm{BH})$ h before a single herbage meal, during continuous culture fermentation

\begin{tabular}{|c|c|c|c|c|c|}
\hline \multirow[b]{2}{*}{ Parameter } & \multicolumn{3}{|c|}{ Treatment } & \multirow[b]{2}{*}{ SEM } & \multirow[b]{2}{*}{$P$-value } \\
\hline & $\mathrm{CON}$ & $9 \mathrm{BH}$ & $1 \mathrm{BH}$ & & \\
\hline \multicolumn{6}{|l|}{ Nutrient ruminal digestibility } \\
\hline True OM digestibility, \% & 78.2 & 77.7 & 79.6 & 1.56 & 0.71 \\
\hline Apparent NDF digestibility, \% & $84.9^{\mathrm{x}}$ & $80.5^{y}$ & $82.8^{x y}$ & 0.08 & 0.08 \\
\hline True CP digestibility, \% & 85.3 & 83.1 & 86.1 & 2.41 & 0.72 \\
\hline Ruminal pH & $6.6^{\mathrm{a}}$ & $5.6^{\mathrm{c}}$ & $6.5^{\mathrm{b}}$ & 0.02 & $<0.01$ \\
\hline \multicolumn{6}{|l|}{$\mathrm{VFA}, \mathrm{m} M$} \\
\hline Total & $88.0^{\mathrm{b}}$ & $92.6^{\mathrm{a}}$ & $93.3^{\mathrm{a}}$ & 1.74 & 0.09 \\
\hline Acetate & 45.1 & 44.8 & 44.9 & 2.94 & 0.99 \\
\hline Propionate & $18.7^{\mathrm{b}}$ & $20.4^{\mathrm{a}}$ & $18.2^{\mathrm{b}}$ & 0.34 & 0.01 \\
\hline Butyrate & $17.2^{\mathrm{y}}$ & $18.1^{\mathrm{y}}$ & $21.7^{\mathrm{x}}$ & 1.32 & 0.06 \\
\hline Valerate & 5.65 & 8.07 & 7.39 & 1.724 & 0.42 \\
\hline Isobutyrate & 0.62 & 0.49 & 0.44 & 0.06 & 0.14 \\
\hline Isovalerate & 0.59 & 0.51 & 0.69 & 2.71 & 0.83 \\
\hline Acetate:propionate & $2.39^{\mathrm{a}}$ & $2.02^{\mathrm{b}}$ & $2.45^{\mathrm{a}}$ & 0.134 & 0.03 \\
\hline
\end{tabular}


Table 3. Nitrogen metabolism of orchardgrass herbage only $(\mathrm{CON})$ and orchardgrass herbage plus corn silage fed either $1(1 \mathrm{BH})$ or $9(9 \mathrm{BH})$ h before a single herbage meal, during continuous culture fermentation

\begin{tabular}{|c|c|c|c|c|c|}
\hline \multirow[b]{2}{*}{ Item } & \multicolumn{3}{|c|}{ Treatment } & \multirow[b]{2}{*}{ SEM } & \multirow[b]{2}{*}{$P$-value } \\
\hline & $\mathrm{CON}$ & $9 \mathrm{BH}$ & $1 \mathrm{BH}$ & & \\
\hline $\mathrm{NH}_{3}-\mathrm{N}, \mathrm{mg} / 100 \mathrm{~mL}$ & $18.69^{\mathrm{a}}$ & $8.88^{\mathrm{c}}$ & $11.37^{\mathrm{b}}$ & 0.417 & $<0.01$ \\
\hline \multicolumn{6}{|l|}{ Effluent $\mathrm{N}$ flows, $\mathrm{g} / \mathrm{d}$} \\
\hline Total N & $1.19^{\mathrm{a}}$ & $0.91^{\mathrm{b}}$ & $0.87^{\mathrm{b}}$ & 0.052 & 0.02 \\
\hline $\mathrm{NH}_{3}-\mathrm{N}$ & $0.42^{\mathrm{a}}$ & $0.20^{\mathrm{c}}$ & $0.26^{\mathrm{b}}$ & 0.009 & $<0.01$ \\
\hline Non- $\mathrm{NH}_{3}-\mathrm{N}$ & 0.78 & 0.71 & 0.62 & 0.041 & 0.17 \\
\hline Bacterial N & 0.60 & 0.54 & 0.50 & 0.031 & 0.25 \\
\hline Dietary N & 0.18 & 0.17 & 0.12 & 0.054 & 0.75 \\
\hline \multicolumn{6}{|l|}{ Effluent $\mathrm{N}$ flows, $\%$ of total $\mathrm{N}$ flow } \\
\hline $\mathrm{NH}_{3}-\mathrm{N}$ & $36.3^{\mathrm{a}}$ & $22.7^{\mathrm{b}}$ & $31.39^{\mathrm{a}}$ & 1.77 & 0.02 \\
\hline Non- $\mathrm{NH}_{3}-\mathrm{N}$ & $63.7^{\mathrm{b}}$ & $77.3^{\mathrm{a}}$ & $68.6^{\mathrm{b}}$ & 1.70 & 0.02 \\
\hline Bacterial $\mathrm{N}, \%$ of total non- $\mathrm{NH}_{3}-\mathrm{N}$ flow & 78.3 & 75.6 & 82.1 & 6.20 & 0.83 \\
\hline Dietary $\mathrm{N}, \%$ of total non- $\mathrm{NH}_{3}-\mathrm{N}$ flow & 21.7 & 24.4 & 17.9 & 6.50 & 0.83 \\
\hline \multicolumn{6}{|l|}{ Bacterial efficiency } \\
\hline $\mathrm{g}$ of $\mathrm{N} / \mathrm{kg}$ of $\mathrm{OM}$ truly digested & 11.6 & 10.4 & 9.5 & 0.56 & 0.14 \\
\hline
\end{tabular}

${ }^{a-c}$ Means with different superscripts within rows are different $(P<0.05)$.

was considerably lower (37\%) compared with that used in the present study (56\%). Kolver et al. (1998) reported values of true OM digestibility averaging $87 \%$. Both Kolver et al. (1998) and Bargo et al. (2003b) supplemented the orchardgrass herbage with a cornbased concentrate without affecting OM digestibility. The lack of a timing of supplementation effect on OM digestibility is consistent with previous results of Valk (1994), who did not find any effect of timing of corn silage feeding on in vivo or in vitro OM digestibility. Valk (1994) fed dairy cows with grass-based diets, allocating the corn silage either after milking times or in the evening $(1830 \mathrm{~h})$.

The NDF digestibility reported here is slightly lower than that reported by Kolver et al. (1998) and Bargo et al. (2003b) when supplementing orchardgrass herbage under continuous culture fermentation studies, but consistent with the in vivo results of Valk (1994). The latter study also reported a null effect of timing of corn silage supplementation on NDF digestibility, which supports the present results. The tendency for lower NDF digestibility in 9BH compared with $1 \mathrm{BH}$ could be associated with differences in $\mathrm{pH}$ (Table 2) and its patterns.

\section{Ruminal Fermentation}

A significant effect of the $9 \mathrm{BH}$ treatment on both mean and diurnal variations in ruminal $\mathrm{pH}$ (Table 2) was consistent with a large body of literature (Bargo et al., 2003a). The diurnal fluctuations in $\mathrm{pH}$ relate to the feeding pattern (Figure 1a) of each treatment. Although the postfeeding decline in $\mathrm{pH}$ is expected, the pattern of the decrease when corn silage was fed alone (0700 and 1500 for $9 \mathrm{BH}$ and $1 \mathrm{BH}$, respectively, Figure 1a) suggests a significant change in fermentation that might also have affected the ruminal microflora population dynamics (Van Nevel and Demeyer 1979; Leedle et al., 1982). Although $9 \mathrm{BH}$ affected $\mathrm{pH}$ and $\mathrm{NH}_{3}-\mathrm{N}$ concentration, overall effects on concentrations of total VFA and OM digestibility were not significant.

The differences in total VFA concentration between CON and supplemented treatments relate mainly to the greater concentration of propionate for $9 \mathrm{BH}$ and butyrate for $1 \mathrm{BH}$ (Table 2). Despite the lack of difference in total VFA concentration between $9 \mathrm{BH}$ and $1 \mathrm{BH}$, the timing of feeding corn silage had a significant effect on the pattern of fermentation. With the same acetate concentration, 9BH had a greater propionate concentration throughout the day, suggesting that $9 \mathrm{BH}$ feeding may supply more glucogenic precursors for the animal compared with $1 \mathrm{BH}$ or CON treatments. Generally, modifications of the nutrients supplied by the rumen to the host animal are achieved through modifications to dietary inputs that affect the ruminal fermentation patterns (Van Soest, 1982; France and Dijkstra, 2005) and microbial dynamics (Van Nevel and Demeyer, 1979; Leedle et al., 1982). The changes observed for $1 \mathrm{BH}$ and $9 \mathrm{BH}$ in rumen microbial fermentation patterns were achieved without any change in the diet or in the amount of each feed source allocation, but by altering the ruminal metabolism through changes in the timing of feeding. Such a change in pattern of nutrient supply is also supported by the difference in butyrate concentrations (Table 2) and patterns of valerate and isobutyrate concentrations at different times of the day (data not shown).

\section{Nitrogen Metabolism}

As expected, $\mathrm{N}$ intake was significantly reduced by corn silage supplementation, and this accounted for 

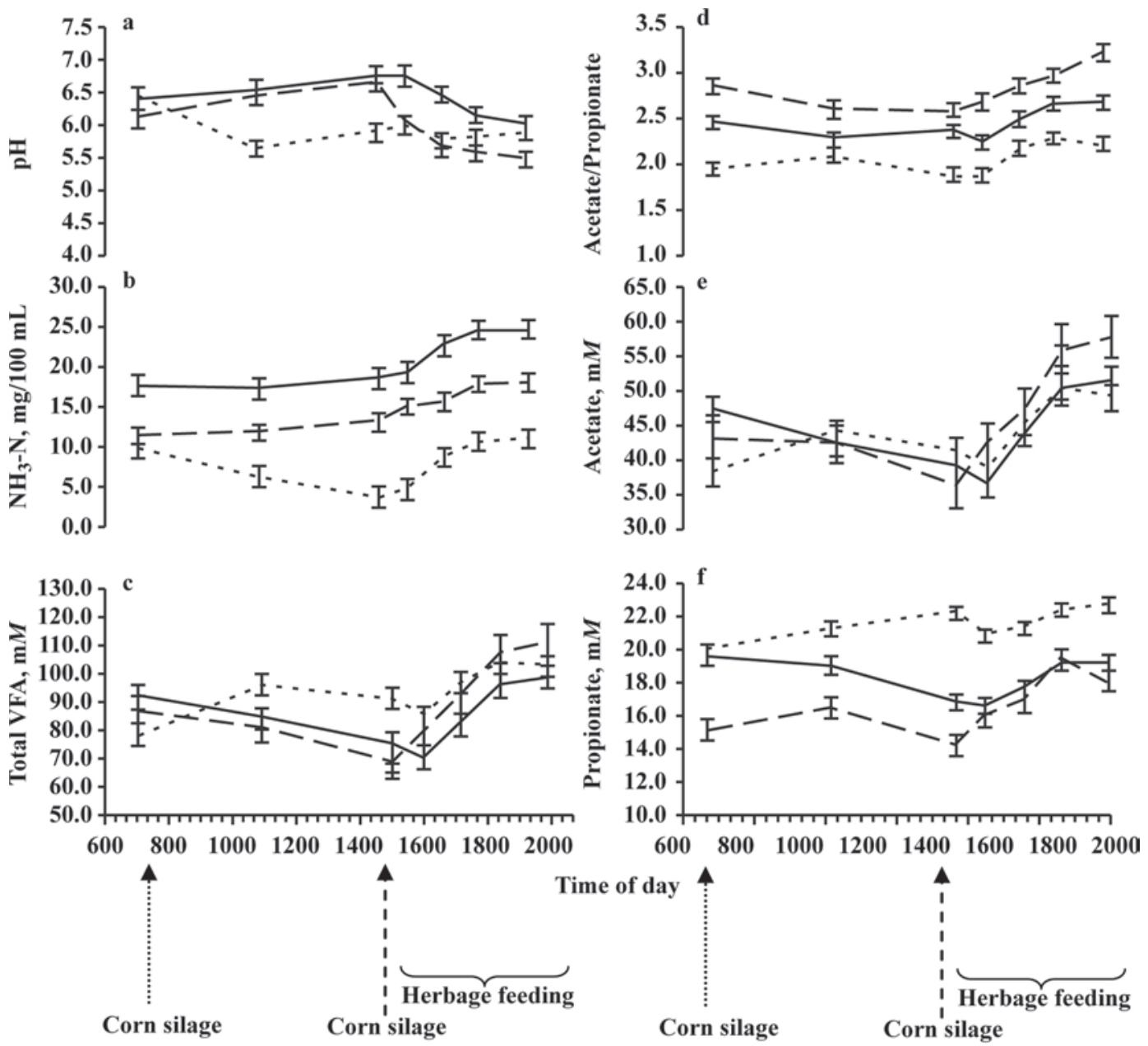

feeding for 9BH

feeding for $1 \mathrm{BH}$

feeding for 9BH feeding for $1 \mathrm{BH}$

Figure 1. Diurnal patterns of a) ruminal $\mathrm{pH}$, b) $\mathrm{NH}_{3}-\mathrm{N}$, c) total VFA, d) acetate:propionate ratio, e) acetate, and f) propionate during continuous culture fermentation of orchardgrass herbage only $(\mathrm{CON} ;-)$ and orchardgrass herbage plus corn silage fed 1 (1BH; -- -$)$ or 9 $(9 \mathrm{BH} ;$-----) h before a single herbage meal.

the decrease in ruminal $\mathrm{NH}_{3}-\mathrm{N}$ concentration because bacterial $\mathrm{N}$ were not affected by treatment (Table 3 ). The decrease in ruminal $\mathrm{NH}_{3}-\mathrm{N}$ for the treatments receiving corn silage was sustained throughout the day (Figure 1b). The magnitude of such a decrease was much greater when the corn silage was fed $9 \mathrm{~h}$ before the intensive orchardgrass meal (9BH vs. $1 \mathrm{BH})$, which might relate to steadier microbial growth over a 24-h period. A potential steadier microbial growth probably relates to the higher frequency of nutrient supply to the microbial population in $9 \mathrm{BH}$ compared with $1 \mathrm{BH}$ and CON. Similar effects on ruminal $\mathrm{NH}_{3}-\mathrm{N}$ concentration were reported by Graf et al. (2005) with grazing dairy cows, where the effect of corn silage feeding on ruminal $\mathrm{NH}_{3}-\mathrm{N}$ concentration was evident approximately $10 \mathrm{~h}$ after the corn silage meal. In contrast, Mitani et al. (2005) did not find any effect of timing of corn silage supplementation on ruminal $\mathrm{NH}_{3}-\mathrm{N}$ of grazing dairy cows. In their experiment, Mitani et al. (2005) fed cows corn silage $2 \mathrm{~h}$ before or immediately after a 5 -h grazing period. Although Mitani et al. (2005) attempted to prepare the rumen microbial population for a single herbage meal, it appears that $2 \mathrm{~h}$ was not sufficient time to affect ruminal microbial populations and products of fermentation (i.e., $\mathrm{NH}_{3}-\mathrm{N}$ concentrations). The work of Mitani et al. (2005) matches the results of $\mathrm{NH}_{3} \mathrm{~N}$ concentrations obtained with the treatment $1 \mathrm{BH}$ in the present study, which evidences the benefit of better timing of corn silage supplementation as in $9 \mathrm{BH}$.

The distribution of $\mathrm{NH}_{3}-\mathrm{N}$ in the effluent (Table 3) indicates an important effect of corn silage supplementation on ruminal utilization of $\mathrm{N}$ by reducing $\mathrm{NH}_{3}-\mathrm{N}$ concentration (Valk, 1994; Romera et al., 2007). Lower $\mathrm{NH}_{3}-\mathrm{N}$ losses from the $9 \mathrm{BH}$ treatment, compared with 
$1 \mathrm{BH}$, are consistent with the results mentioned above, indicating that strategic timing of corn silage supplementation (e.g., 9BH) might reduce $\mathrm{N}$ losses as $\mathrm{NH}_{3}-\mathrm{N}$ (e.g., gaseous $\mathrm{NH}_{3}$ excretions) from cows grazing lush pastures, and to some extent reduce $\mathrm{N}$ excretion in urine (Romera et al., 2007; Pinares-Patiño et al., 2009).

Previous studies using continuous culture fermenter systems that replaced herbage with starch (Kolver et al., 1998) or corn-based concentrates (Bach et al., 1999; Bargo et al., 2003b) did not report changes in bacterial $\mathrm{N}$ flow $(\mathrm{g} / \mathrm{d})$. Although timing of supplementation (9BH vs. $1 \mathrm{BH})$ did not have a significant effect on bacterial efficiency, in the context of the present results the numerical increase $(9.5 \%)$ for 9BH merits further study, because such a potential difference may enable changes to be made in rumen microbial population dynamics.

\section{CONCLUSIONS}

Timing supplementation of corn silage at $9 \mathrm{~h}$ rather than $1 \mathrm{~h}$ before a short and intensive herbage meal improved $\mathrm{N}$ utilization by reducing $\mathrm{NH}_{3}-\mathrm{N}$ concentration and flow, which was supported by the reduction in ruminal $\mathrm{NH}_{3}-\mathrm{N}$ concentration by $30 \%$. Moreover, supplementing corn silage $9 \mathrm{~h}$ instead of $1 \mathrm{~h}$ before a short and intensive herbage meal appears to increase the supply of glucogenic nutrients (propionate) by $13 \%$. Under the same herbage allocation, a simple change in timing of supplementation may improve utilization of nutrients supplied by pasture. In conjunction with grazing management including restricted access to pasture to avoid damage in wet conditions, appropriate timing of supplementation might help to mitigate pollutant losses of $\mathrm{N}$. In vivo studies are required to confirm the benefits of timing of corn silage supplementation on the release of urea $\mathrm{N}$ to the environment.

\section{ACKNOWLEDGMENTS}

We thank Melissa Rubano, Leah Ruth, Kristina McAllister, and Felipe Montes (USDA-ARS Pasture Systems and Watershed Management Research Unit, University Park, PA) for their invaluable help during the sample collection period and analysis, as well as Barbara Dow for her help with the statistical analyses and data interpretation. The authors also acknowledge Alvaro Romera, Cameron Clark, and Pierre Beukes from DairyNZ (Hamilton, New Zealand) for their critical review, ideas, and comments on the manuscript.

\section{REFERENCES}

Adams, D. C. 1985. Effect of time of supplementation on performance, forage intake and grazing behavior of yearling beef steers grazing Russian wild ryegrass in the fall. J. Anim. Sci. 61:1037-1042.
AOAC. 2000. Official Methods of Analysis. 17th ed. Association of Official Analytical Chemists, Gaithersburg, MD.

Bach, A., I. K. Yoon, M. D. Stern, H. G. Jung, and H. ChesterJones. 1999. Effects of type of carbohydrate supplementation to lush pasture on microbial fermentation in continuous culture. J. Dairy Sci. 82:153-160.

Bargo, F., L. D. Muller, E. S. Kolver, and J. E. Delahoy. 2003a. Invited review: Production and digestion of supplemented dairy cows on pasture. J. Dairy Sci. 86:1-42.

Bargo, F., G. A. Varga, L. D. Muller, and E. S. Kolver. 2003b. Pasture intake and substitution rate effects on nutrient digestion and nitrogen metabolism during continuous culture fermentation. J. Dairy Sci. 86:1330-1340.

Blackwell, M. B. 1993. Experiences with on-off grazing in early lactation on dairy farms in Northland. Proc. N.Z. Soc. Anim. Prod. 53:37-39.

Chilibroste, P., P. Soca, D. A. Mattiauda, O. Bentancur, and P. H. Robinson. 2007. Short-term fasting as a tool to design effective grazing strategies for lactating dairy cattle: A review. Aust. J. Exp. Agric. 47:1-10.

de Klein, C. A. M., and S. F. Ledgard. 2001. An analysis of environmental and economic implications of nil and restricted grazing systems designed to reduce nitrate leaching from New Zealand dairy farms. I. Nitrogen losses. N. Z. J. Agric. Res. 44:201-215.

de Veth, M. J., and E. S. Kolver. 2001. Digestion of ryegrass pasture in response to change in $\mathrm{pH}$ in continuous culture. J. Dairy Sci. 84:1449-1457.

France, J., and J. Dijkstra. 2005. Volatile fatty acid production. Pages 157-175 in Quantitative Aspects of Ruminant Digestion and Metabolism. J. Dijkstra, M. Forbes, and J. France, ed. CABI, Wallingford, UK.

Gekara, O. J., E. C. Prigge, W. B. Bryan, E. L. Nestor, and G. Seidel. 2005. Influence of sward height, daily timing of concentrate supplementation, and restricted time for grazing on forage utilization by lactating beef cows. J. Anim. Sci. 83:1435-1444.

Graf, C. M., M. Kresuer, and F. Dohme. 2005. Effects of supplemental hay and corn silage versus full-time grazing on ruminal $\mathrm{pH}$ and chewing activity of dairy cows. J. Dairy Sci. 88:711-725.

Gregorini, P., C. E. F. Clark, J. G. Jago, C. B. Glassey, K. L. M. McLeod, and A. J. Romera. 2009. Restricting time at pasture: Effects on dairy cow herbage intake, foraging behavior, hungerrelated hormones and metabolite concentration during the first grazing session. J. Dairy Sci. 92:4572-4580.

Gregorini, P., S. A. Gunter, and P. A. Beck. 2008. Matching plant and animal processes to alter nutrient supply in strip grazed cattle: Timing of herbage and fasting allocation. J. Anim. Sci. 86:10061020.

Griswold, K. E., W. H. Hoover, T. K. Miller, and W. V. Thayne. 1996. Effect of form of nitrogen on growth of ruminal microbes in continuous culture. J. Anim. Sci. 74:483-491.

Hall, M. B., W. H. Hoover, J. P. Jennings, and T. K. Miller Webster. 1999. A method for partitioning neutral detergent soluble carbohydrates. J. Sci. Food Agric. 79:2079-2086.

Holmes, C. W.. I. M. Brookes, D. J. Garrick, D. D. S. MacKenzie, T. J. Parkinson, and G. F. Wilson. 2002. Milk Production from Pasture. Principles and Practices. Massey University, Wellington, New Zealand.

Hoover, W. H., T. K. Miller, S. R. Stokes, and W. V. Thayne. 1989. Effects of fish meals on rumen bacterial fermentation in continuous culture. J. Dairy Sci. 72:2991-2998.

Kennedy, E., M. O'Donovan, M. McEvoy, and J. P. Murphy. 2009 Effect of restricted access time to pasture on dairy cow milk production, grazing behavior and dry matter intake. J. Dairy Sci. 92:168-176.

Kolver, E. S., and M. J. de Veth. 2002. Prediction of ruminal pH from pasture-based diets. J. Dairy Sci. 85:1255-1266.

Kolver, E. S., L. D. Muller, and G. A. Varga. 1998. Ruminal utilization of pasture nitrogen in response to inclusion of dietary starch. Proc. N.Z. Soc. Anim. Prod. 58:106-109.

Leedle, J. A. Z., M. P. Bryant, and R. B. Hespell. 1982. Diurnal variation of bacterial numbers and fluid parameters in ruminal 
contents on animals fed low- or high-forage diets. Appl. Environ. Microbiol. 44:402-412.

Makkar, H. P., and K. Becker. 1999. Purine quantification in digesta from ruminants by spectrophotometric and HPLC methods. Br. J. Nutr. 81:107-112.

Mattiauda, D. A., F. Elizondo, S. Tamminga, and P. Chilibroste. 2003. Effect of the length and moment of grazing session on milk production and composition of grazing dairy cows. Trop. Subtrop. Agroecosyst. 3:87-90.

McLeod, K. L. M., C. E. F. Clark, C. B. Glassey, P. Gregorini, D. A. Costall, K. Betteridge, and J. G. Jago. 2009. Strategically reducing time on pasture: Dairy cow intake, production, welfare, and excretory behavior. Proc. N.Z. Soc. Anim. Prod. 69:15-19.

Mitani, T., M. Takahashi, K. Ueda, H. Nakatsuji, and S. Kondo. 2005. Effects of pre-feeding of a corn silage-based supplement on the feed intake, milk production and nitrogen utilization of grazing dairy cows. Anim. Sci. J. 76:453-460.

Payne, R. W., S. A. Harding, D. A. Murray, D. M. Soutar, D. B. Baird, A. I. Glaser, I. C. Channing, S. J. Welham, A. R. Gilmour, R. Thompson, and R. Webster. 2008. GenStat Release 11 Reference Manual, Part 2 Directives. VSN International, Hemel Hempstead, UK.

Pérez-Ramirez, E., R. Delagarde, and J. L. Payreaud. 2009. Restricting daily time at pasture at low and high herbage allowance: Effects on herbage intake and behavioral adaptation of lactating dairy cows. J. Dairy Sci. 92:3331-3340.

Pinares-Patiño, C. S., G. C. Waghorn, R. S. Hegarty, and S. O. Hoskin. 2009. Effects of intensification of pastoral farming on greenhouse gas emissions in New Zealand. N. Z. Vet. J. 57:252-261.

Romera, A. J., C. C. Palliser, and P. C. Beukes. 2007. Reducing nitrogen leaching in pastoral dairy farm by replacing nitrogen fertilizer by maize silage. Pages 600-604 in Proc. Australasian Dairy Sci. Conf. D. F. Chapman, D. A Clark, K. L. Macmillan, and D. P. Nation ed. Nat. Dairy Alliance, Univ. Melbourne, Victoria, Australia.

Soder, K. J., L. S. Saporito, and W. L. Stout. 2007. Effect of byproduct gypsum application rate to grass pasture, grass hay, and corn silage on fermentation by rumen microorganisms in continuous culture. Anim. Feed Sci. Technol. 132:331-340.

Stern, M. D., and W. H. Hoover. 1990. The dual flow continuous culture system. Page 1 in Fermenters or Frustration. NEADSAASAS Workshop, W. H. Miner Agric. Res. Inst., Chazy, NY.
Tamminga, S. 1996. A review on environmental impacts of nutritional strategies in ruminants. J. Anim. Sci. 74:3112-3124.

Valk, H. 1994. Effect of partial replacement of herbage by maize silage on N-utilization and milk production of dairy cows. Livest. Prod. Sci. 40:241-250.

Van Nevel, C. J., and D. I. Demeyer. 1979. Stoichiometry of carbohydrate fermentation and microbial growth efficiency in a continuous culture of mixed rumen bacteria. Eur. J. Appl. Microbiol. Biotechnol. 7:111-120.

Van Soest, P. J. 1982. Nutritional Ecology of the Ruminants. O \& B Books, Corvallis, OR.

Van Soest, P. J., J. B. Robertson, and B. A. Lewis. 1991. Methods for dietary fiber, neutral detergent fiber and non-starch polysaccharides in relation to animal nutrition. J. Dairy Sci. 74:3583-3597.

Verbyla, A. P., B. R. Cullis, M. G. Kenward, and S. J. Welham. 1999. The analysis of designed experiments and longitudinal data by using smoothing splines (with discussion). Appl. Stat. 48:269311 .

Wales, W. J., E. S. Kolver, P. L. Thorne, and A. R. Egan. 2004. Diurnal variation in ruminal $\mathrm{pH}$ on the digestibility of highly digestible perennial ryegrass during continuous culture fermentation. J. Dairy Sci. 87:1864-1871.

Weiss, W. P., H. R. Conrad, and N. R. St. Pierre. 1992. A theoreticallybased model for predicting total digestible nutrient values of forages and concentrates. Anim. Feed Sci. Technol. 39:95-110.

Weller, R. A., and A. F. Pilgrim. 1974. Passage of protozoa and volatile fatty acids from the rumen of the sheep and from a continuous in vitro fermentation system. Br. J. Nutr. 32:341-351.

Yang, C. M. J., and G. A. Varga. 1989. Effect of three concentrate feeding frequencies on rumen protozoa, rumen digesta kinetics, and milk yield in dairy cows. J. Dairy Sci. 79:950-957.

Zinn, R. A., and F. N. Owens. 1986. A rapid procedure for purine measurements and its use for estimating net ruminal protein synthesis. Can. J. Anim. Sci. 66:157-166. 